\title{
Pembelajaran Everyone Is Teacher Here Dan Pengaruhnya Terhadap Hasil Belajar Matematika Siswa
}

\author{
${ }^{1}$ Musnaeni \\ ${ }^{2}$ Nasaruddin \\ 2Institut Agama Islam Negeri (IAIN) Palopo \\ Jl. Agatis, Kel. Balandai, Kota Palopo, Sulawesi Selatan, Indonesia \\ E-mail:2nasaruddin@iainpalopo.ac.id
}

\begin{abstract}
The main problem in this research is the teachers who do not use effective learning methods. One interesting learning methods to be implemented is the Everyone Is Teacher Here methods. It gives the opportunity for each student to act as a teacher for his friends. The research is experimental study using pretest-posttest control design. The technique of collecting data through observation and tests. The population is all students of class IX SMP Muhammadiayah Palopo many as 43 students. Based on the results of descriptive data analysis showed that the control class and experimental class before treatment with less category with an average of 57.14 and 55.73. Meanwhile, after treatment showed that the control class is in the category simply mean $=71.81$ and the experimental class in both categories with mean $=78.73$. So we can conclude that there is influence in terms of qualitative and quantitative terms occur due to the different categories of learning outcomes and the average value of students, in other words, there is the effect of the application of Everyone Is Teacher Here methods the results of students' mathematics learning in SMP Muhammadiyah Palopo
\end{abstract}

Keywords: Everyone is Teacher Here Learning, Mathematics Evaluation Result.

\begin{abstract}
Abstrak
Pokok permasalahan dalam penelitian ini adalah adanya guru yang belum menggunakan metode pembelajaran yang efektif. Salah satu metode pembelajaran yang menarik untuk dilaksanakan adalah metode pembelajaran Everyone Is Techer Here. Metode pembelajaran Everyone Is Teacher Here memberi kesempatan kepada setiap siswa untuk berperan sebagai guru bagi kawan-kawannya. Penelitian yang digunakan adalah penelitian eksperimen dengan menggunakan Pretest-Posttest Control Design. Teknik pengumpulan data melalui observasi dan tes. Populasi yang digunakan adalah seluruh siswa kelas IX SMP Muhammadiayah Palopo sebanyak 43 orang siswa. Berdasarkan hasil analisis data deskriptif diperoleh bahwa kelas kontrol dan kelas eksperimen sebelum perlakuan berkategori kurang dengan rata-rata $=57,14$ dan 55,73. Sedangkan setelah perlakuan diperoleh bahwa kelas kontrol berada pada kategori cukup dengan rata-rata $=71,81$ dan kelas eksperimen pada kategori baik dengan rata-rata $=78,73$. Jadi dapat disimpulkan bahwa ada pengaruh dari segi kualitatif dan dari segi kuantitatif dikarenakan terjadi perbedaan kategori hasil belajar dan nilai rata-rata siswa, dengan kata lain ada pengaruh penerapan metode pembelajaran Everyone Is Teacher Here terhadap hasil belajar matematika siswa di SMP Muhammadiyah Palopo.
\end{abstract}

Kata Kunci: Pembelajaran Everyone is Teacher Here, Hasil Belajar Matematika. 


\section{Pendahuluan}

Pendidikan merupakan suatu upaya yang dilakukan agar seorang anak dapat mencapai tujuan tertentu. Untuk mencapai tujuan tersebut diperlukan adanya pembelajaran yang mampu membantu seorang anak memperoleh haknya sebagai peserta didik, salah satunya yaitu mampu meningkatkan hasil belajarnya. Salah satu pelajaran yang dianggap berperan penting dalam pencapaian tujuan pendidikan adalah pelajaran matematika. Matematika bukan hanya sekedar segala sesuatu yang berhubungan dengan angka dan bilangan. Matematika seperti halnya musik atau seni yang lainnya, merupakan satu dari sekian sarana untuk mengembangkan sebuah kesadaran diri yang sempurna di dalam diri ${ }^{1}$. Penggunaan matematika dalam kehidupan manusia dilakukan sehari-hari. Dilihat dari segi manfaatnya matematika perlu diajarkan dengan pembelajaran yang efektif.

Pembelajaran merupakan suatu sistem atau proses membelajarkan subjek didik yang direncanakan atau didesain, dilaksanakan, dan dievaluasi secara sistematis agar subjek didik dapat mencapai tujuan-tujuan pembelajaran ${ }^{2}$. Tugas guru dalam rangka optimalisasi proses belajar adalah sebagai fasilitator yang mampu mengembangkan kemampuan anak.

Bertitik tolak dari penjelasan tersebut di atas, maka seorang guru diharapkan memiliki kemampuan dalam memilih strategi apa yang tepat digunakan untuk melaksanakan proses pembelajaran di kelasnya, sehingga tujuan yang telah dituliskan dalam rencana pengajaran dapat tercapai. Jadi jelaslah bahwa seorang guru dituntut untuk menguasai metode. Langkahlangkah yang harus ditempuh oleh seorang guru sebelum pembuatan metode adalah memperhatikan persiapan mengajar (lesson plan) yang meliputi pemahaman terhadap tujuan pendidikan, penguasaan materi pelajaran, dan pemahaman teori-teori pendidikan selain teori-teori pengajaran.

Salah satu metode pembelajaran yang perlu diterapkan oleh guru untuk membuat kelas menjadi aktif dan menyenangkan serta meningkatkan hasil belajar siswa yaitu dengan menerapkan metode pembelajaran Everyone Is Teacher Here. Metode pembelajaran Everyone Is Teacher Here (setiap orang adalah guru) merupakan metode yang dapat digunakan untuk meningkatkan proses pembelajaran siswa, dan dapat disesuaikan dengan tujuan yang ingin dicapai oleh pembelajaran pada berbagai mata pelajaran.

${ }^{1}$ Evawati Alisah and Eko Prasetyo, Filsafat Dunia Matematika Pengantar Untuk Memahami Konsep-Konsep Matematika (Jakarta: Prestasi Pustaka Publisher, 2007), 38.

${ }^{2}$ Kokom Komalasari, Pembelajaran Kontekstual Konsep Dan Aplikasi, III (Bandung: Refika Aditama, 2013), 3. 
Metode pembelajaran Everyone Is Teacher Here mampu memberi kesempatan kepada setiap siswa untuk berperan sebagai guru bagi kawankawannya. Dengan metode ini, siswa yang selama ini tidak mau terlibat akan ikut serta dalam pembelajaran secara aktif. Metode ini dapat diterapkan sesuai dengan materi yang diajarkan, tujuannya untuk menghilangkan kejenuhan siswa dalam belajar. Metode pembelajaran Everyone Is Teacher Here adalah salah satu metode dalam model pembelajaran kooperatif (Cooperative Learning). Menurut Sudjana metode pembelajaran Everyone Is Teacher Here adalah metode pembelajaran yang digunakan oleh guru dengan maksud meminta siswa untuk semuanya berperan menjadi narasumber terhadap semua temannya di kelas belajar. ${ }^{3}$

Langkah-langkah penerapan metode pembelajaran Everyone Is Teacher Here ini adalah sebagai berikut ${ }^{4}$ :

1. Bagikan selembar kertas berukuran kecil yang telah berisikan nomor absen dari setiap siswa kepada seluruh siswa.

2. Seluruh siswa diminta menuliskan satu pertanyaan mengenai materi pelajaran yang sedang diajarkan atau topik khusus yang sedang didiskusikan didalam kelas.

3. Kertas dikumpulkan dan diacak, kemudian dibagikan kepada setiap siswa (pastikan tidak ada siswa yang menerima soal yang dibuatnya sendiri).

4. Setiap siswa diminta membaca soal yang diterimanya dalam hati dan memikirkan jawabannya.

5. Mintalah kepada satu persatu siswa secara sukarela untuk membacakan jawabannya.

6. Siswa yang lain memberikan tanggapan atas jawaban yang telah dibacakan oleh temannya.

3 “Metode Pembelajaran Everyone Is Teacher," accessed February 22, 2014, http://thesun-nani.blogspot.com/2012/10/metode-pembelajaran-everyone-is-teacher.html.

${ }^{4}$ Agus Suprijono, Cooperatif Learning (Yogyakarta: Pustaka Pelajar, 2009), 110. 
Dengan demikian, melalui metode Everyone Is Teacher Here tersebut, hasil yang diharapkan adalah:

1. Setiap diri masing-masing siswa berani mengemukakan pendapat (menyatakan dengan benar) melalui jawaban atas pertanyaan yang telah dibuatnya berdasarkan sumber bacaan yang diberikan.

2. Mampu mengemukakan pendapat melalui tulisan dan menyatakannya di depan kelas.

3. Siswa lain, yang berani mengemukakan pendapat dan menyatakan kesalahan jawaban dari siswa lain yang disanggah.

4. Terlatih dalam menyimpulkan masalah dan hasil kajian pada masalah yang dikaji.

Adapun kelebihan dan kekurangan metode pembelajaran Everyone Is Teacher Here adalah sebagai berikut:

1. Metode pembelajaran Everyone Is Teacher Here mempunyai beberapa kelebihan diantaranya: (1). Pertanyaan dapat menarik dan memusatkan perhatian siswa, sekalipun ketika itu siswa sedang ribut, yang mengantuk kembali segar; (2). Merangsang siswa untuk melatih dan mengembangkan daya pikir, termasuk daya ingatan; dan (3). Mengembangkan keberanian dan keterampilan siswa dalam menjawab dan mengemukakan pendapat.

2. Sedangkan kekurangan metode pembelajaran Everyone Is Teacher Here antara lain: (1). Memerlukan banyak waktu untuk menyelesaikan soalsoal pada kelas yang memiliki jumlah siswa yang banyak.; (2). Siswa merasa takut mengemukakan pendapatanya apabila guru kurang dapat mendorong siswa untuk berani, dengan menciptakan suasana yang tidak tegang.; dan (3). Tidak mudah membuat pertanyaan yang sesuai dengan tingkat berpikir dan mudah dipahami siswa.

\section{Metode Penelitian}

Jenis penelitian yang dilakukan adalah penelitian eksperimen. Penelitian eksperimen adalah metode penelitian yang digunakan untuk mencari pengaruh perlakuan tertentu terhadap yang lain dalam kondisi yang terkendalikan ${ }^{5}$. Penelitian ini adalah penelitian yang bertujuan melihat hubungan sebab-akibat. Penelitian ini dilakukan di kelas IX SMP Muhammadiyah Palopo yang beralamat di Jl. K. H. Ahmad Dahlan Desa/Kelurahan Amassangan kota Palopo. Populasi dalam penelitian ini adalah seluruh siswa kelas IX SMP Muhammadiyah Palopo. Siswa kelas IX SMP Muhammadiyah Palopo terdiri dari dua kelas yaitu Kelas IX A dengan jumlah siswa 21 orang dan kelas IX B dengan jumlah siswa 22 orang.

\footnotetext{
${ }^{5}$ Sugiyono, Metode Penelitian Pendidikan Pendekatan Kuantitatif, Kualitatif, Dan $R$ \& $D$ (Bandung: Alfabeta, 2013), 72.
} 
Penelitian ini terdiri dari dua variabel yang diamati, yakni variabel $\mathrm{X}$ dan variabel Y. Hasil belajar matematika siswa yang diajar dengan menerapkan metode pembelajaran Everyone Is Teacher Here dikategorikan sebagai variable $\mathrm{X}$, dan hasil belajar matematika siswa yang diajar dengan menerapkan metode pembelajaran konvensional dikategorikan sebagai variable Y. Adapun desain penelitian eksperimen yang digunakan dalam penelitian ini adalah True Experimental Design bentuk Pretest-Posttest Control Design. Adapun gambaran desain penelitiannya seperti yang terlihat pada Tabel 1 berikut:

Tabel 1. Desain Penelitian

\begin{tabular}{|c|c|c|c|}
\hline Kelompok & Pre-tes & Perlakuan & Post-tes \\
\hline Eksperimen & $\mathrm{Y}_{1}$ & $\mathrm{X}_{1}$ & $\mathrm{Y}_{2}$ \\
\hline Kontrol & $\mathrm{Y}_{3}$ & - & $\mathrm{Y}_{4}$ \\
\hline
\end{tabular}

Keterangan :

$\mathrm{X}_{1}$ : Perlakuan dengan penerapan metode pembelajaran Everyone Is Teacher Here pada kelas eksperimen.

$\mathrm{Y}_{1}$ : Hasil belajar matematika siswa kelas eksperimen sebelum perlakuan penerapan metode pembelajaran Everyone Is Teacher Here.

$\mathrm{Y}_{2}$ : Hasil belajar matematika siswa kelas eksperimen setelah perlakuan penerapan metode pembelajaran Everyone Is Teacher Here.

$\mathrm{Y}_{3}$ : Hasil belajar matematika siswa kelas kontrol diajar dengan pembelajaran biasa atau konvensional.

$\mathrm{Y}_{4}$ : Hasil belajar matematika siswa kelas kontrol yang diajar dengan pembelajaran biasa atau konvensional.

Adapun tehnik pengolahan dan analisis data yaitu terdiri dari analisis uji coba instrumen dan analisis data kelompok eksperimen dan kelompok kontrol. Analisis uji coba intrumen terdiri dari validitas dan reabilitas. Validitas yang digunakan dalam penelitian ini yaitu validitas isi. Sedangkan nilai reliabilitas perangkat pembelajaran diperoleh dari lembar penilaian yang telah diisi oleh tiga validator. Rumus yang digunakan adalah rumus percentage of Agreements yang telah dimodifikasi. 


$$
R=\frac{\overline{d(A)}}{\overline{d(A)}+\overline{d(D)}}
$$

Keterangan:

$\mathrm{R} \quad:$ = Koefisien Reliabilitas

d(A) : Rerata Derajat Agreements dari Penilai

d(D) : Rerata Derajat Disagreement dari Penilai

Adapun analisis data kelompok eksperimen dan kelompok kontrol data dianalisis dengan analisis statistik deskriptif. Analisis statistik deskriptif digunakan untuk mendeskripsikan karakteristik responden berupa rata-rata, varians, dan standar deviasi hasil beajar matematika siswa, baik responden pada kelas eksperimen maupun responden pada kelas kontrol.

Untuk menghitung nilai rata-rata (mean) data tunggal frekuensi lebih dari satu kita dapat menggunakan rumus berikut ${ }^{6}$ :

Keterangan :

$$
\text { Mean }=\bar{x}=\frac{\sum x_{i} \cdot f_{i}}{n}
$$

$\overline{\mathrm{x}} \quad$ : Rata-rata (mean)

$\Sigma \quad$ : Epsilon (baca jumlah)

$\mathrm{x}_{\mathrm{i}} \quad$ : Nilai $\mathrm{x}$ ke i sampai ke $\mathrm{n}$

$f_{i} \quad$ : Frekuensi masing-masing skor $\left(x_{i}\right)$

$\mathrm{N} \quad$ : jumlah individu atau frekuensi.

Sedangkan untuk menghitung varians sampel kita dapat mengguakan rumus berikut ${ }^{7}$ :

$$
\sigma^{2}=\frac{n \sum_{1}^{n} f_{i} x_{i}^{2}-\left(\sum_{1}^{n} f_{i} x_{i}\right)^{2}}{n(n-1)}
$$

Dan untuk standar deviasinya adalah akar dari varians, yaitu:

$$
\sigma=\sqrt{\frac{n \sum_{1}^{n} f_{i} x_{i}{ }^{2}-\left(\sum_{1}^{n} f_{i} x_{i}\right)^{2}}{n(n-1)}}
$$

Keterangan :

$\sigma^{2} \quad$ : Variansi populasi

$\sigma \quad$ : Standar Devisi Populasi

$\Sigma \quad$ : Epsilon (baca jumlah)

$\mathrm{X}_{\mathrm{i}} \quad$ : nilai $\mathrm{x} 1$ sampai ke $\mathrm{i}$

$\mathrm{F}$ : frekuensi

$\mathrm{N} \quad$ : Jumlah individu.

\footnotetext{
${ }^{6}$ Furqon, Statistika Penerapan Untuk Penelitian, IX (Bandung: CV Alfabeta, 2013), 49.

${ }^{7}$ Ibid., 63.
} 
Sedangkan untuk mengetahui hasil belajar siswa digunakan pedoman pengkategorian predikat hasil belajar yang berlaku di SMP Muhammadiyah Palopo seperti yang terlihat pada Tabel 2 berikut:

Tabel 2. Kategori Predikat Hasil Belajar

\begin{tabular}{|c|c|}
\hline Nilai & Kategori \\
\hline $0-64$ & Kurang \\
\hline $65-75$ & Cukup \\
\hline $76-85$ & Baik \\
\hline $86-100$ & Sangat Baik \\
\hline
\end{tabular}

Adapun Kriteria Ketuntasan Minimal (KKM) yang harus dipenuhi seorang siswa yang ada di SMP Muhammadiyah Palopo adalah 65 (KKM ditentukan oleh pihak Sekolah). Jika seorang siswa memperoleh skor $\geq 65$ maka siswa yang bersangkutan mencapai ketuntasan individu, dan siswa yang memperoleh skor $<65$ maka siswa yang bersangkutan dinyatakan tidak tuntas.

\section{Pembahasan}

Berdasarkan penelitian yang telah dilakukan, diperoleh data hasil penelitian. Hasil analisis instrumen penelitian yaitu Perhitungan validasi dari hasil penelitian tiga orang ahli dalam bidang pendidikan matematika menunjukkan bahwa rata-rata skor total dari beberapa indikator penilaian soal pre-tes $(\bar{X})$ adalah 3,585 dan rata-rata skor total dari beberapa indikator penilaian soal post-tes $(\bar{X})$ adalah 3,613. Dengan demikian dapat disimpulkan bahwa soal pre-tes dan post-tes yang berkaitan dengan pokok bahasan kesebangunan segitiga, telah memenuhi kategori kevalidan yaitu "3,5 $\leq M \leq 4$ " yang dinilai sangat valid. Sedangkan, hasil uji reliabilitas diperoleh $(R)$ pre-tes sebesar 0,898 dan $(\mathrm{R})$ post-tes sebesar 0,905. Dengan demikian dapat disimpulkan bahwa soal pre-tes dan post-tes yang berkaitan dengan pokok bahasan kesebangunan segitiga, telah memenuhi kategori reliabel yaitu " $0,81 \leq R \leq 1,00$ " yang dinilai derajat reliabilitasnya sangat tinggi. 
Berdasarkan hasil analisis data kelas kontrol dan kelas eksperimen, deskripsi data hasil belajar matematika siswa sebelum diberi perlakuan (konvensional) pada kelas kontrol diperoleh data sebagaimana yang dipaparkan dalam Tabel 3 berikut:

Tabel 3. Statistik Deskriptif Pre-Test Kelas Kontrol

\begin{tabular}{|c|l|c|}
\hline No. & \multicolumn{1}{|c|}{ Statistik } & Nilai Statistik \\
\hline 1. & Jumlah Siswa $(\mathrm{n})$ & 21 \\
\hline 2. & Skor Rata-rata (Mean) & 57,14 \\
\hline 3. & Variansi $(\sigma 2)$ & 83,429 \\
\hline 4. & Standar Deviasi $(\sigma)$ & 9,134 \\
\hline
\end{tabular}

Selanjutnya untuk mengetahui gambaran hasil belajar matematika siswa yang dilihat melalui hasil pre-tes secara kuantitatif pada kelas kontrol, dapat dilihat dari perbandingan persentase jumlah siswa yang memiliki hasil belajar matematika seperti Tabel 4 berikut:

Tabel 4. Keadaan Pre-test Kelas Kontrol

\begin{tabular}{|c|c|c|c|c|}
\hline No. & Interval Skor & Interpretasi & Frekuensi & Persentase (\%) \\
\hline 1. & $86-100$ & Sangat Baik & 0 & $0 \%$ \\
\hline 2. & $76-85$ & Baik & 0 & $0 \%$ \\
\hline 3. & $65-75$ & Cukup & 3 & $14,29 \%$ \\
\hline 4. & $0-64$ & Kurang & 18 & $85,71 \%$ \\
\hline \multicolumn{3}{|c|}{ Jumlah } & 21 & $100 \%$ \\
\hline
\end{tabular}

Sedangkan ketuntasan hasil belajar matematika siswa pada kelas kontrol dapat dilihat pada Tabel 5 berikut:

Tabel 5. Ketuntasan Siswa Kelas Kontrol

\begin{tabular}{|c|c|c|c|c|}
\hline No. & Interval Skor & Interpretasi & Frekuensi & Persentase (\%) \\
\hline 1. & $65-100$ & Tuntas & 3 & $14,29 \%$ \\
\hline 2. & $0-64$ & Tidak Tuntas & 18 & $85,71 \%$ \\
\hline \multicolumn{3}{|c|}{ Jumlah } & 21 & $100 \%$ \\
\hline
\end{tabular}

Berdasarkan tabel diatas dapat disimpulkan bahwa hasil belajar matematika siswa di kelas kontrol tergolong masih sangat rendah dengan melihat persentase ketuntasan yang hanya 14,29\%. 
Hasil pre-tes untuk mengetahui kemampuan awal siswa pada kelas eksperimen sebelum diberi perlakuan (metode pembelajaran Everyone Is Teacher Here) diperoleh data Tabel 6 berikut:

Tabel 6. Statistik Deskriptif Pre-Test Kelas Eksperimen

\begin{tabular}{|c|c|c|}
\hline No. & Statistik & Nilai Statistik \\
\hline 1. & Jumlah Siswa $(\mathrm{n})$ & 22 \\
\hline 2. & Skor Rata-rata (Mean) & 55,73 \\
\hline 3. & Variansi $(\sigma 2)$ & 65,636 \\
\hline 4. & Standar Deviasi $(\sigma)$ & 8,102 \\
\hline
\end{tabular}

Selanjutnya untuk mengetahui gambaran hasil belajar matematika siswa yang dilihat melalui hasil pre-tes secara kuantitatif pada kelas eksperimen, dapat dilihat melalui Tabel 7 berikut:

Tabel 7. Keadaan Pre-Test Kelas Eksperimen

\begin{tabular}{|c|c|c|c|c|}
\hline No. & Interval Skor & Interpretasi & Frekuensi & Persentase (\%) \\
\hline 1. & $86-100$ & Sangat Baik & 0 & $0 \%$ \\
\hline 2. & $76-85$ & Baik & 0 & $0 \%$ \\
\hline 3. & $65-75$ & Cukup & 2 & $9,09 \%$ \\
\hline 4. & $0-64$ & Kurang & 20 & $90,91 \%$ \\
\hline \multicolumn{2}{|c|}{ Jumlah } & 22 & $100 \%$ \\
\hline
\end{tabular}

Selain itu, untuk mengetahui ketuntasan hasil belajar matematika siswa pada kelas eksperimen dapat dilihat pada Tabel 8 berikut:

Tabel 8. Ketuntasan Siswa Kelas Eksperimen

\begin{tabular}{|c|c|c|c|c|}
\hline No. & Interval Skor & Interpretasi & Frekuensi & Persentase (\%) \\
\hline 1. & $65-100$ & Tuntas & 2 & $9,09 \%$ \\
\hline 2. & $0-64$ & Tidak Tuntas & 20 & $90,91 \%$ \\
\hline \multicolumn{3}{|c|}{ Jumlah } & 22 & $100 \%$ \\
\hline
\end{tabular}

Berdasarkan Tabel 8 dapat disimpulkan bahwa hanya ada 2 siswa yang tuntas dengan presentase 9,09\% dan 20 siswa yang tidak tuntas dengan persentase 90,91\%. Maka secara umum dapat disimpulkan bahwa hasil belajar matematika siswa di kelas eksperimen tergolong masih sangat rendah dengan melihat persentase ketuntasan yang hanya 9,09\%. 
Dengan melihat hasil deskripsi kelas kontrol dan kelas eksperimen, secara umum dapat disimpulkan bahwa kedua kelas diperoleh hasil belajar yang masih tergolong sangat rendah dengan persentase ketuntasan untuk kelas kontrol adalah 14,29\% sedangkan kelas eksperimen 9,09\%.

Hasil analisis data post-tes tentang hasil belajar matematika siswa yang di ajar dengan metode konvensional pada pokok bahasan kesebangunan segitiga pada kelas kontrol dipaparkan dalam Tabel 9 sebagai berikut:

Tabel 9. Keadaan Post-test Kelas Kontrol

\begin{tabular}{|c|c|c|}
\hline No. & Statistik & Nilai Statistik \\
\hline 1. & Jumlah Siswa $(\mathrm{n})$ & 21 \\
\hline 2. & Skor Rata-rata (Mean) & 71,81 \\
\hline 3. & Variansi $(\sigma 2)$ & 19,562 \\
\hline 4. & Standar Deviasi $(\sigma)$ & 4,423 \\
\hline
\end{tabular}

Gambaran hasil belajar matematika siswa yang dilihat melalui hasil post-tes secara kuantitatif pada kelas kontrol, dapat dilihat melalui Tabel 10 berikut:

Tabel 10. Keadaan Post-Test Kelas Kontrol

\begin{tabular}{|c|c|c|c|c|}
\hline No. & Interval Skor & Interpretasi & Frekuensi & Persentase (\%) \\
\hline 1. & $86-100$ & Sangat Baik & 0 & $0 \%$ \\
\hline 2. & $76-85$ & Baik & 6 & $28,57 \%$ \\
\hline 3. & $65-75$ & Cukup & 14 & $66,67 \%$ \\
\hline 4. & $0-64$ & Kurang & 1 & $4,76 \%$ \\
\hline \multicolumn{3}{|c|}{ Jumlah } & 21 & $100 \%$ \\
\hline
\end{tabular}

Selanjutnya ketuntasan hasil belajar matematika siswa pada kelas kontrol dapat dilihat pada Tabel 11 berikut:

Tabel 11. Ketuntasan Siswa Kelas Kontrol

\begin{tabular}{|c|c|c|c|c|}
\hline No. & Interval Skor & Interpretasi & Frekuensi & Persentase (\%) \\
\hline 1. & $65-100$ & Tuntas & 20 & $95,24 \%$ \\
\hline 2. & $0-64$ & Tidak Tuntas & 1 & $4,76 \%$ \\
\hline \multicolumn{3}{|c|}{ Jumlah } & 21 & $100 \%$ \\
\hline
\end{tabular}


Hasil analisis statistik deskriptif post-test kelas eksperimen mengenai hasil belajar matematika siswa yang diajar dengan menerapkan metode pembelajaran Everyone Is Teacher Here pada pokok bahasan kesebangunan segitiga, dipaparkan melalui Tabel 12 berikut:

Tabel 12. Keadaan Post-test Kelas Eksperimen

\begin{tabular}{|c|c|c|}
\hline No. & Statistik & Nilai Statistik \\
\hline 1. & Jumlah Siswa $(\mathrm{n})$ & 22 \\
\hline 2. & Skor Rata-rata (Mean) & 78,73 \\
\hline 3. & Variansi $(\sigma 2)$ & 48,969 \\
\hline 4. & Standar Deviasi $(\sigma)$ & 6,998 \\
\hline
\end{tabular}

Gambaran hasil belajar matematika siswa yang dilihat melalui hasil post-tes secara kuantitatif pada kelas eksperimen, dapat dilihat melalui Tabel 13 berikut:

Tabel 13. Keadaan Post-Test Kelas Eksperimen

\begin{tabular}{|c|c|c|c|c|}
\hline No. & Interval Skor & Interpretasi & Frekuensi & Persentase (\%) \\
\hline 1. & $86-100$ & Sangat Baik & 7 & $31,82 \%$ \\
\hline 2. & $76-85$ & Baik & 9 & $40,91 \%$ \\
\hline 3. & $65-75$ & Cukup & 6 & $27,27 \%$ \\
\hline 4. & $0-64$ & Kurang & 0 & $0 \%$ \\
\hline \multicolumn{3}{|c|}{ Jumlah } & 22 & $100 \%$ \\
\hline
\end{tabular}

Dengan demikian dapat disimpulkan bahwa skor hasil belajar matematika siswa yang diukur melalui hasil post-tes untuk kelas eksperimen termasuk dalam kategori baik (B) dengan frekuensi 9 siswa dengan persentase 40,91\%. Selanjutnya untuk mengetahui ketuntasan hasil belajar matematika siswa pada kelas eksperimen dapat dilihat pada tabel berikut:

Tabel 14. Ketuntasan Siswa Kelas Kontrol

\begin{tabular}{|c|c|c|c|c|}
\hline No. & Interval Skor & Interpretasi & Frekuensi & Persentase (\%) \\
\hline 1. & $65-100$ & Tuntas & 22 & $100 \%$ \\
\hline 2. & $0-64$ & Tidak Tuntas & 0 & $0 \%$ \\
\hline \multicolumn{3}{|c|}{ Jumlah } & 22 & $100 \%$ \\
\hline
\end{tabular}


Berdasarkan Tabel 14 tersebut dapat disimpulkan bahwa tidak ada siswa yang tidak tuntas, atau dengan kata lain dari 20 siswa dikelas eksperimen semua siswa memenuhi Kriteria Ketuntasan Minimal (KKM) yang telah di tetapkan oleh Sekolah. Sedangkan dari hasil observasi yang dilakukan untuk melihat keefektivan siswa dalam menerima pelajaran dengan menggunakan daftar cek, dengan penerapan metode pembelajaran Everyone Is Teacher Here pada kelas eksperimen lebih mendorong siswa untuk aktif dalam proses pembelajaran dengan terlibat langsung.

Berdasar dari hasil analisis tersebut, maka secara deskriptif diperoleh bahwa hasil belajar matematika siswa kelas IX SMP Muhammadiyah Palopo sebelum diterapkan metode pembelajaran Everyone Is Teacher Here lebih rendah dari pada hasil belajar matematika sesudah diterapkan metode pembelajaran Everyone Is Teacher Here. Sehingga dapat disimpulkan bahwa terdapat pengaruh dari segi kualitatif karena terjadinya perbedaan peningkatan kategori hasil belajar matematika siswa dan terdapat pula pengaruh dari segi kuantitatif karena terjadi perbedaan nilai rata-rata siswa, salah satunya disebabkan adanya perbedaan perlakuan yaitu metode pembelajaran dengan penerapan metode pembelajaran Everyone Is Teacher Here.

\section{Penutup}

Berdasarkan masalah-masalah yang telah dikemukakan dan dirumuskan sebelumnya maka hasil penelitian ini dapat disimpulkan sebagai berikut.

1. Rata-rata hasil pre-tes siswa kelas IX SMP Muhammadiyah Palopo yang tidak menerapkan metode pembelajaran Everyone Is Teacher Here adalah 57,14 dengan kategori kurang. Sedangkan rata-rata hasil post-tes siswa kelas IX SMP Muhammadiyah Palopo yang tidak menerapkan metode pembelajaran Everyone Is Teacher Here adalah 71,81 dengan kategori cukup.

2. Rata-rata hasil pre-tes siswa kelas IX SMP Muhammadiyah Palopo yang menerapkan metode pembelajaran Everyone Is Teacher Here adalah 55,73 dengan kategori kurang. Sedangkan rata-rata hasil post-tes siswa kelas IX SMP Muhammadiyah Palopo yang menerapkan metode pembelajaran Everyone Is Teacher Here adalah 78,73 dengan kategori baik.

3. Dari hasil statistik deskriptif dapat disimpulkan bahwa ada pengaruh penerapan metode pembelajaran Everyone Is Teacher Here terhadap hasil belajar matematika siswa di SMP Muhammadiyah Palopo. Pengaruh dari segi kualitatif terlihat pada perbedaan kategori hasil belajar matematika siswa sebelum dan sesudah perlakuan yaitu pre-tes kelas 
kontrol berkategori kurang dan post-tes berkategori cukup, sedangkan pre-tes kelas eksperimen berkategori kurang dan post-tes berkategori baik. Adapun pengaruh dari segi kuantitatif terlihat pada perbedaan nilai rata-rata siswa sebelum dan sesudah perlakuan yaitu pre-tes kelas kontrol adalah 57,14 dan post-tes adalah 71,81, sedangkan pre-tes kelas eksperimen adalah 55,73 dan post-tes adalah 78,73.

\section{Daftar Pustaka}

Alisah, Evawati, and Eko Prasetyo. Filsafat Dunia Matematika Pengantar Untuk Memahami Konsep-Konsep Matematika. Jakarta: Prestasi Pustaka Publisher, 2007.

Furqon. Statistika Penerapan Untuk Penelitian. IX. Bandung: CV Alfabeta, 2013.

Komalasari, Kokom. Pembelajaran Kontekstual Konsep Dan Aplikasi. III. Bandung: Refika Aditama, 2013.

"Metode Pembelajaran Everyone Is Teacher." Accessed February 22, 2014. http://thesun-nani.blogspot.com/2012/10/metode-pembelajaraneveryone-is-teacher.html.

Sugiyono. Metode Penelitian Pendidikan Pendekatan Kuantitatif, Kualitatif, Dan $R \&$ D. Bandung: Alfabeta, 2013.

Suprijono, Agus. Cooperatif Learning. Yogyakarta: Pustaka Pelajar, 2009. 
Musnaeni \& Nasaruddin

Halaman ini sengaja dikosongkan

Al-Khwarizmi - 28 